\title{
Studies on the absorption of zinc by rat intestine
}

\author{
BY N. T. DAVIES \\ Rowett Research Institute, Bucksburn, Aberdeen AB2 $9 S B$
}

(Received I4 May 1979 - Accepted 14 August 1979)

I. A technique is described for the measurement of the extent of ${ }^{a s} \mathrm{Zn}$ absorption by different regions of the intestine in the intact rat. Using this technique it was shown that the duodenum contributed $60 \%$, the ileum $30 \%$ and the jejunum $10 \%$ to the over-all absorption of ${ }^{85} \mathrm{Zn}$. Negligible absorption of ${ }^{85} \mathrm{Zn}$ occurred from the caecum and colon.

2. Using ligated loops of rat duodenum in situ, ${ }^{85} \mathrm{Zn}$ absorption was shown to be rapid, with $\mathrm{I} \%$ of a $5 \mu \mathrm{g}$ dose being transferred to the carcase within I min of intraluminal dosing.

3. When ${ }^{65} \mathrm{Zn}$ was injected into ligated loops in a dose range of $\mathrm{I}-200 \mu \mathrm{g} \mathrm{Zn} / \mathrm{ml}$ the rate of absorption was linear with respect to time over the first $15 \mathrm{~min}$. The rates of ${ }^{\circ 5} \mathrm{Zn}$ absorption $v$. dose of ${ }^{\circ 5} \mathrm{Zn}$ exhibited saturation kinetics indicating absorption by a 'carrier' or enzyme-mediated process.

4. The binding of ${ }^{86} \mathrm{Zn}$ to loop tissue showed biphasic kinetics which suggested that at low intraluminal concentrations of $\mathrm{Zn}(\mathrm{I}-50 \mu \mathrm{g} \mathrm{Zn} / \mathrm{ml})$ binding was to specific sites whereas, at higher concentrations (50-200 $\mu \mathrm{g} \mathrm{Zn} / \mathrm{ml})$, non-specific binding occurred.

5. A study of the fate of mucosally bound ${ }^{65} \mathrm{Zn}$ showed that over the first $30 \mathrm{~min}$ a proportion of the ${ }^{\circ} \mathrm{Zn}$ was rapidly transferred to the carcase and this was probably associated with the rapid phase of ${ }^{65} \mathrm{Zn}$ absorption described previously. From $30 \mathrm{~min}$ up to $6 \mathrm{~h}$ after the initial binding, ${ }^{\circ 6} \mathrm{Zn}$ was also transferred to the carcase albeit at a much slower rate indicating a slow phase of $\mathrm{Zn}$ absorption. A study of the kinetics of this slow phase indicated that the loss of bound ${ }^{65} \mathrm{Zn}$ to the body was a saturable process indicating an enzyme- or 'carrier'-mediated process. A comparison of the kinetics of the slow and rapid phases of ${ }^{\circ} \mathrm{Zn}$ absorption suggests that these processes are distinct.

6. Histological examination of mucosal tissue of loops exposed to $200 \mu \mathrm{g} \mathrm{Zn} / \mathrm{ml}$ revealed no discernable damage. Similarly, no effect was observed on either arginine or glucose uptake by isolated duodenal loops in situ, although this concentration of $\mathrm{Zn}$ completely abolished fluid uptake. A study of the effect of different doses of $\mathrm{Zn}$ showed that $50 \mu \mathrm{g} \mathrm{Zn} / \mathrm{ml}$ inhibited mucosal fluid uptake by more than $50 \%$ and $100 \mu \mathrm{g} \mathrm{Zn} / \mathrm{ml}$ by more than $90 \%$. It was concluded that these effects were due to a specific action on the fluid-transfer process and not due to a general poisoning of the mucosa.

Early studies on zinc absorption in rats (Feaster et al. 1955) led the authors to characterize $\mathrm{Zn}$ absorption as poor. Despite numerous reports to the contrary in rats (Forbes \& Yohe, 1960; Forbes, 1961 ; Heth \& Hoekstra, 1965), mice (Cotzias et al. 1962), pigs (Whiting \& Bezeau, 1958) and humans (Spencer et al. 1965) it is still widely accepted that $\mathrm{Zn}$ is 'poorly absorbed' (Underwood, 1971).

Studies to determine the site of intestinal absorption in rats indicate that absorption occurs more rapidly in the duodenum than either the ileum or jejunum and negligible absorption occurs in either the stomach or distal to the caecum (Van Campen \& Mitchell, 1965; Methfessel \& Spencer, 1973a). In both these investigations, absorption was measured by a technique involving injection of a dose of ${ }^{65} \mathrm{Zn}$ into ligated segments of different regions of the intestine. The relative rates of absorption were measured either directly from the loss of injected ${ }^{65} \mathrm{Zn}$ activity from the loop (Methfessel \& Spencer, 1973a) or inferred from the appearance of absorbed ${ }^{65} \mathrm{Zn}$ in body tissues (Van Campen \& Mitchell, 1965). However, since no account was taken of the different rates of passage of digesta through these different intestinal regions, studies of this nature cannot show what contribution each segment of the intestine makes to the over-all absorption of dietary $\mathrm{Zn}$. Accordingly in this present investigation, a technique was adopted which enabled the fractional absorption of a dose of ${ }^{83} \mathrm{Zn}$ by different regions of the intestine to be measured in intact animals.

The mechanisms involved in gastrointestinal absorption of $\mathrm{Zn}$ are poorly understood. 
Following the recent separation of metal-binding proteins of low molecular weight in intestinal mucosa (Starcher, 1969; Evans et al. 1970; Suso \& Edwards, 197 I $a, b$; Van Campen \& Kowalski, I97I) suggestions have been made that these may function as 'carrier' proteins or may function as a mucosal block to the intestinal absorption of copper (Evans \& Johnson, 1978) and $\mathrm{Zn}$ (Richards \& Cousins, 1976). However, apart from competition studies showing that high concentrations of $\mathrm{Zn}$ inhibit copper absorption (Van Campen, 1966; Van Campen \& Scaife, 1967) and conversely that high concentrations of $\mathrm{Cu}$ inhibit Zn absorption (Van Campen, 1969) no kinetic information has been published showing that $\mathrm{Zn}$ is transported across the mucosa by a saturable process.

In order to gain further insight into the mechanism of $\mathrm{Zn}$ absorption a study has been made of the kinetics of ${ }^{65} \mathrm{Zn}$ absorption from ligated duodenal loops.

A preliminary report of some of these findings has already been published (Davies, 1973).

\section{METHODS \\ Animals}

In all experiments male rats of the Rowett Hooded Lister strain were used. Their weights ranged from 150 to $200 \mathrm{~g}$.

\section{Diets}

All animals received a stock pelleted diet offered $a d$ lib. from weaning. At $\mathrm{I} 8 \mathrm{~h}$ before receiving anaesthetic, food was withdrawn and the rats were allowed access to distilled water only.

\section{${ }^{65} \mathrm{Zn}$ absorption by different regions of the intestine in intact rats}

The technique described by Heth \& Hoekstra (1965) for estimation of the 'true-percentage' absorption of a dose of ${ }^{65} \mathrm{Zn}$ was modified to enable the extent of $\mathrm{Zn}$ absorption by different regions of the intestine to be measured. Twenty-five rats were allocated at random to five groups each of five rats. For $2 \mathrm{~d}$ before treatment all rats were offered a $\mathrm{Zn}$-deficient diet (Williams \& Mills, I 970) so that the $\mathrm{Zn}$ concentration of the gut contents was sufficiently low not to alter significantly the specific activity of the test dose of ${ }^{65} \mathrm{Zn}$. Food was withdrawn I $8 \mathrm{~h}$ before dosing. The rats were anaesthetized under diethyl ether and the abdominal cavity opened by a midline incision. A $10 \mu \mathrm{g}$ test dose of ${ }^{65} \mathrm{Zn}$ (as zinc chloride, specific activity $0.5 \mu \mathrm{Ci} / \mu \mathrm{g}$ ) in $0.1 \mathrm{ml}$ sterile saline ( $9 \mathrm{~g}$ sodium chloride/l) was injected by means of a fine-bore syringe needle into the lumen of either the duodenum (immediately distal to the pyloric sphincter), jejunum ( $200 \mathrm{~mm}$ distal to the pyloric sphincter), ileum ( $200 \mathrm{~mm}$ proximal to the ileo-caecal junction) or caecum (immediately distal to the ileo-caecal junction). The fifth group of rats were subjected to laparotomy but the ${ }^{65} \mathrm{Zn}$ was administered as an intramuscular injection into the hind leg.

Immediately after the wounds were closed, the rats were assayed for ${ }^{65} \mathrm{Zn}$ in a whole-body gamma-counter (Nuclear Enterprises, Sighthill, Scotland), and then transferred to clean cages in a warm room and allowed free access to distilled water and the stock cube diet. For the next $5 \mathrm{~d}$ the ${ }^{65} \mathrm{Zn}$ contents of the rats were assayed daily and assayed again on the 8 th day at the termination of the experiment. From the semi-logarithmic ${ }^{65} \mathrm{Zn}$ retention curves obtained, the percentage of dose absorbed for rats dosed in different regions of the intestine was calculated by the method of Heth \& Hoekstra (1965). The relative contribution by each region under study could therefore be assessed by successive subtraction of the total absorption of ${ }^{65} \mathrm{Zn}$ when injected into the more distal region from that of the adjacent proximal region and expressing the results as a percentage of that absorbed by the entire small and large intestine. 
${ }^{65} \mathrm{Zn}$ absorption from ligated loops of duodenum in situ

Rats were anaesthetized with Nembutal ( $45 \mathrm{mg} / \mathrm{kg}$ intraperitoneally) and the peritoneal cavity opened by midline incision. The duodenum (150 mm segment distal to the pyloric sphincter) was flushed with $5 \mathrm{ml}$ warm saline and ligated loops prepared and filled with $\mathrm{I} \mathrm{ml}$ saline containing the test dose of $\mathrm{Zn}(\mathrm{I}-200 \mu \mathrm{g} \mathrm{Zn}$ as zinc sulphate containing $0 \cdot \mathrm{I}-\mathrm{I} \cdot 0 \mu \mathrm{Ci}$ ${ }^{65} \mathrm{Zn}$; The Radiochemical Centre, Amersham, Bucks), as described by Davies \& Nightingale (1975).

In a study of the early time-course of ${ }^{65} \mathrm{Zn}$ absorption, the loop was rapidly excised from I to $5 \mathrm{~min}$ after dosing, and the remaining carcase assayed for ${ }^{65} \mathrm{Zn}$ in a whole-body gammacounter. In other experiments the loops were excised at intervals varying from 5 to $60 \mathrm{~min}$ after dosing, cut open and the contents flushed out with $5 \mathrm{ml}$ warm saline. The loop contents and washings, and the loop tissue were separately assayed for ${ }^{65} \mathrm{Zn}$ in a gamma-well counter (Tracerlab Instruments Division, ICN Pharmaceutical Ltd, Hersham, Surrey). In these experiments $\mathrm{Zn}$ absorption from loop to carcase was assessed from the loss of the injected ${ }^{65} \mathrm{Zn}$ activity (injected activity - activity recovered in loop contents and washings and loop tissue).

${ }^{65} \mathrm{Zn}$ bound' refers to the activity remaining in the loop tissue after the flushing procedure. All results were converted to $\mu \mathrm{g} \mathrm{Zn}$ from the initial specific activity of the injected ${ }^{85} \mathrm{Zn}$ dose.

\section{Zn secretion into duodenal loops}

In order to assess whether appreciable amounts of $\mathrm{Zn}$ might be secreted into the duodenal loops which could alter the specific activity of the injected ${ }^{65} \mathrm{Zn}$, duodenal loops were isolated in situ as described previously and filled with $1.0 \mathrm{ml}$ warm saline previously rendered $\mathrm{Zn}$-free by passage through a column (10 $\mathrm{mm} \times 100 \mathrm{~mm}$ ) of Chelex-100 resin (100-200 mesh, sodium form; Bio-rad Laboratories, Richmond, California, USA). After I h the loops were removed and their contents and saline washings evaporated to dryness in an oven maintained at $110^{\circ}$. The resulting residues were wet-ashed (conc. sulphuric acid-conc. perchloric acidconc. nitric acid 0.5:I·0:5, by vol.) and assayed for $\mathrm{Zn}$ by atomic absorption spectrophotometry using a Varian-Techtron AA5 (Varian Pty, Melbourne, Australia).

\section{Absorption of mucosally bound ${ }^{65} \mathrm{Zn}$}

The fate of ${ }^{85} \mathrm{Zn}$ bound to the mucosal tissue was investigated in experiments in which duodenal loops were prepared in situ as described previously except that at each end of the loops a cannula (Portex PP 160) was tied in place. At 15 min after intra-luminal dosing with ${ }^{65} \mathrm{Zn}$ (from $\mathrm{I}-50 \mu \mathrm{g} \mathrm{Zn}$ as $\mathrm{ZnSO}_{4}$ in I ml saline containing $0.1 \mu \mathrm{Ci}^{65} \mathrm{Zn}$ ) the lumen contents were flushed out with $10 \mathrm{ml}$ warm saline while the loop remained in situ, by means of the two cannulas. For each dose of $\mathrm{Zn}$ studied, some animals were killed immediately after this procedure, the loops excised and the ${ }^{655} \mathrm{Zn}$ bound' to the loop tissue measured. Groups of rats were subsequently killed at intervals varying from $15 \mathrm{~min}$ to $6 \mathrm{~h}$ and the ${ }^{65} \mathrm{Zn}$ remaining in the loop and contents assayed. The rate of transfer of ${ }^{65} \mathrm{Zn}$ bound to the loop tissue to the carcase was calculated from the difference between ${ }^{65} \mathrm{Zn}$ remaining in the loop and contents at the time of killing and that initially bound. All results were converted to $\mu \mathrm{g} \mathrm{Zn}$ from the initial specific activity of the injected ${ }^{65} \mathrm{Zn}$ dose.

\section{The effect of $\mathrm{Zn}$ on glucose, arginine and fluid absorption}

The effect of high intraluminal $\mathrm{Zn}$ concentration on glucose absorption was investigated using closed ligated duodenal loops prepared as described previously. The loops were filled with I ml saline containing $10 \mu \mathrm{mol}$ glucose and $200 \mu \mathrm{g} \mathrm{Zn} \mathrm{(as} \mathrm{ZnSO}_{4}$ ) or $10 \mu \mathrm{mol}$ glucose alone. After I5 min the loops were excised and the glucose, in a portion of the loop contents and washings, estimated by the method of Nelson (1944) as modified by Somogyi (I945) 


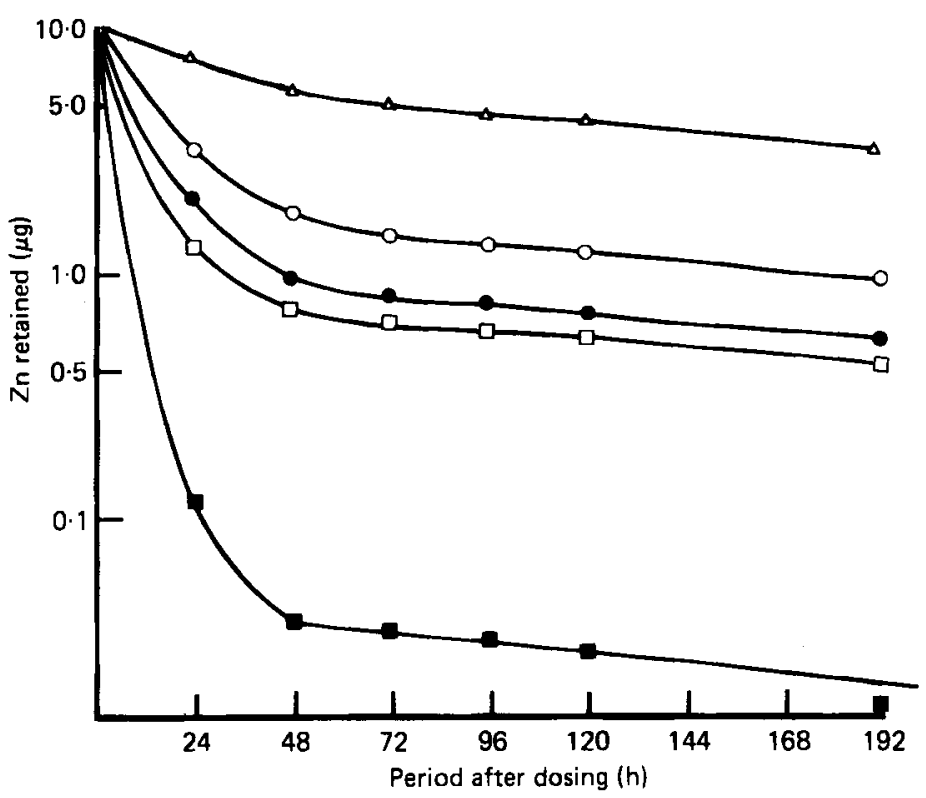

Fig. I. Retention curves for a $10 \mu \mathrm{g}$ dose of zinc labelled with $5 \mu \mathrm{Ci}{ }^{65} \mathrm{Zn}$ after intraluminal injection into the duodenum $(O-O)$, jejunum ( $-O)$, ileum $(\square-\square)$ or caecum ( $\square-\mathbf{a}$ ) or intramuscular $(\triangle-\triangle)$ injection into the hind leg. Each point represents the mean value for five rats. Values for absorption in Table I were derived from the intercepts of the intramuscularly-dosed rats $\left(Y_{1}\right)$ and the intraluminally dosed rats $\left(Y_{2}\right)$ by the equation:

$$
\left(Y_{2} \div Y_{1}\right) \text { 10 } \mu \mathrm{g} \mathrm{Zn} \text {. }
$$

after precipitation of protein with $\mathrm{I} \mathrm{ml} 0.35 \mathrm{M}-\mathrm{ZnSO}_{4}$ and $\mathrm{I} \mathrm{ml} 0.5 \mathrm{M}$-sodium hydroxide. The results were expressed as mucosal uptake of glucose ( $\mu \mathrm{mol} /$ loop per $15 \mathrm{~min}$ ).

The effect of $\mathrm{Zn}$ on mucosal uptake of arginine was similarly investigated. Duodenal loops were filled with I ml warm saline containing $6.88 \mu \mathrm{mol}$ arginine and $200 \mu \mathrm{g} \mathrm{Zn}$ (as $\mathrm{ZnSO}_{4}$ ). After $15 \mathrm{~min}$ the loops were excised and the arginine remaining in the loop contents and washings assayed by the method of Macpherson (1942) after protein precipitation with an equal volume of trichloroacetic acid $(100 \mathrm{~g} / 1)$. The mucosal uptake of arginine was expressed as $\mu \mathrm{mol} / \mathrm{loop}$ per $15 \mathrm{~min}$.

The effect of $\mathrm{Zn}$ on mucosal fluid transfer was investigated using ligated duodenal loops as described previously. At $5 \mathrm{~min}$ after the loops were injected with $\mathrm{I} \cdot 0 \mathrm{ml}$ saline containing doses of $\mathrm{Zn}$ in a range of 0-200 $\mu \mathrm{g} \mathrm{Zn} \mathrm{(as} \mathrm{ZnSO}_{4}$ ), the loops were excised, blotted gently and weighed. After cutting open and emptying the loops, they were gently blotted and reweighed. The difference in weight was used as a measure of the volume of the remaining fluid. The loss of fluid over the $15 \mathrm{~min}$ absorptive period, corresponding to mucosal fluid uptake, was expressed as $\mathrm{ml} /$ loop per $15 \mathrm{~min}$.

\section{RESULTS}

${ }^{65} \mathrm{Zn}$ absorption by different regions of the intestine of intact rats

The first experiment was designed to demonstrate which regions of the intestine are important in the absorption of $\mathrm{Zn}$. Rats were injected with a Io $\mu \mathrm{g}$ dose of ${ }^{65} \mathrm{Zn}$ either intraluminally into the duodenum, ileum or caecum, or intramuscularly into the hind leg, and the ${ }^{65} \mathrm{Zn}$ retention plotted on a logarithmic scale $v$. time on a linear scale (Fig. I). For each treatment, the linear portion of the semi-logarithmic retention curves from 72 to $192 \mathrm{~h}$ post administration, found by regression analysis, had the same slope whether the ${ }^{65} \mathrm{Zn}$ was 
Table 1. The biological half-life $\left(t_{t}\right)$ of body ${ }^{65} \mathrm{Zn}, 72-192 \mathrm{~h}$ after injection of a $10 \mu \mathrm{g}$ test dose of ${ }^{65} \mathrm{Zn}$ (specific activity $0.5 \mu \mathrm{Ci} / \mu \mathrm{g}$ ) into different intestinal regions or intramuscular injection in the hind leg, and the absorption and percentage contribution to over-all absorption of the $10 \mu \mathrm{g}$ dose of ${ }^{65} \mathrm{Zn}$ by different regions of the small and large intestine

(Mean values with their standard errors for five rats/treatment. Biological half-lives, calculated from the regression lines of the semi-logarithmic retention curves for each rat, were pooled within groups for calculation of mean values and standard errors of the means. For calculation of mean absorption of $\mathrm{Zn}$, values for $\mathrm{Zn}$ absorption were derived for each rat from the intercept of the ordinate of the extrapolated linear portion of the retention curve and the mean of the intercepts on the ordinate of the group of rats dosed by intramuscular injection (for explanation, see p. 192))

\begin{tabular}{|c|c|c|c|c|c|}
\hline \multirow[b]{2}{*}{ Region dosed } & \multicolumn{2}{|c|}{$t_{t}$} & \multicolumn{2}{|c|}{$\begin{array}{c}\mathrm{Zn} \text { absorption } \\
(\mu \mathrm{g})\end{array}$} & \multirow{2}{*}{$\begin{array}{c}\text { Contribution } \\
\text { to over-all } \\
\text { absorption }(\%)\end{array}$} \\
\hline & Mean & SE & Mean & SE & \\
\hline Duodenum & 194 & $8 \cdot 7$ & 3.21 & 0.3 & $57^{-9}$ \\
\hline Jejunum & 237 & 22 & $1 \cdot 35$ & 0.35 & $8 \cdot 4$ \\
\hline Ileum & 205 & $5 \cdot 0$ & 1.08 & 0.10 & $30 \cdot 1$ \\
\hline Caecum + colon & 326 & 190 & 0.1 I & 0.03 & $3 \cdot 0$ \\
\hline Intramuscular & 206 & 13.9 & - & - & 一 \\
\hline
\end{tabular}

administered intraluminally or by intramuscular injection, indicating that these tracer doses of ${ }^{65} \mathrm{Zn}$ once inside the body were handled in the same way when absorbed or injected. In brief, the method assumes that extrapolation of the retention curve of ${ }^{85} \mathrm{Zn}$ injected into the body by an intramuscular route to the ordinate $\left(Y_{1}\right)$ indicates the proportion of the original dose present in the linear component under study. Since the injected and absorbed dose of ${ }^{65} \mathrm{Zn}$ were handled in the same way after $72 \mathrm{~h}$ the intercepts on the ordinate of the extrapolated linear component of the intraluminally-dosed animals $\left(Y_{2}\right)$ represented the same proportion of the total ${ }^{85} \mathrm{Zn}$ initially absorbed. The true proportion of the ${ }^{65} \mathrm{Zn}$ dose absorbed can thus be calculated by $\left(Y_{2} \div Y_{1}\right)$. Analysis of this type corrects for the absorption and reexcretion of ${ }^{65} \mathrm{Zn}$ into the gut at early time intervals post administration. Table I shows the amount of $\mathrm{Zn}$ absorbed by animals dosed at different regions of the gut together with the biological half-life of the ${ }^{65} \mathrm{Zn}$ calculated from the regression lines of the retention of ${ }^{65} \mathrm{Zn}$ from 72 to $\mathrm{I} 92 \mathrm{~h}$ post administration. Table I also shows the relative contribution to the over-all absorption of $\mathrm{Zn}$ by each region under study expressed as a percentage of that absorbed by the entire small and large intestine (duodenally-dosed animals). The proximal $200 \mathrm{~mm}$ of the small intestine was the major region for $\mathrm{Zn}$ absorption since over half the total of the ${ }^{65} \mathrm{Zn}$ taken into the body was absorbed from this region. The terminal $200 \mathrm{~mm}$ of the ileum was also a major site at which $\mathrm{Zn}$ was absorbed contributing approximately $30 \%$ of the total $\mathrm{Zn}$ absorption, while only $10 \%$ was contributed by the jejunum and upper ileum. Negligible ${ }^{65} \mathrm{Zn}$ was absorbed by the caecum and colon.

This experiment clearly demonstrated the importance of the duodenum as the main site at which $\mathrm{Zn}$ is absorbed by the intact rat and therefore subsequent studies on the kinetics of $\mathrm{Zn}$ absorption were restricted to this region.

\section{Zn secretion into ligated loops}

Since it was proposed to carry out experiments involving measurement of ${ }^{85} \mathrm{Zn}$ absorption from tied-off loops of rat duodenum, preliminary studies were made of $\mathrm{Zn}$ secretion into the duodenum in order to determine whether $\mathrm{Zn}$ secreted either across the mucosal tissue or in bile might seriously alter the specific activity of the injected dose of ${ }^{65} \mathrm{Zn}$. The amount of $\mathrm{Zn}$ recovered in the loop contents of rats with or without bile duct ligation are shown in 
Table 2. The effect of bile-duct ligation on the recovery of zinc in ligated duodenal loops in situ, I h after they were filled with I $\mathrm{ml} \mathrm{Zn}$-free saline $(9 \mathrm{~g}$ sodium chloride/l)

(Mean values with their standard errors for six rats/treatment)

$\begin{array}{lcc}\text { Treatment } & \text { Mean } & \text { SE } \\ \text { Bile duct ligated } & 0.98 & 0.10 \\ \text { Bile duct intact } & 1.07 & 0.15\end{array}$

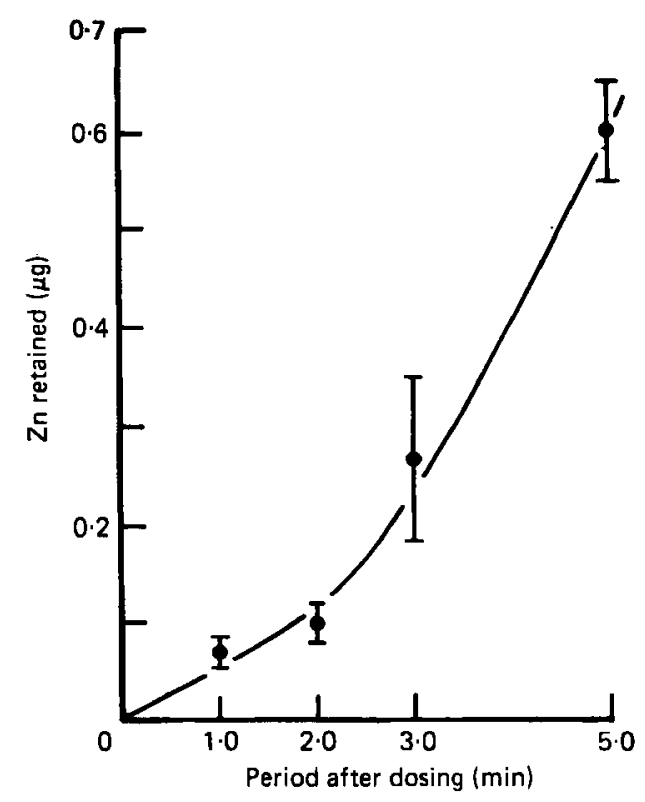

Fig. 2. Early time-courses of absorption of ${ }^{65} \mathrm{Zn}$. Ligated duodenal loops in situ were injected with $5 \mu \mathrm{g} \mathrm{Zn}$ (labelled with $\mathrm{I} \cdot 0 \mu \mathrm{Ci}{ }^{\circ \mathrm{Zn}}$ ) in $\mathrm{I} \cdot 0 \mathrm{ml}$ saline $(9 \mathrm{~g}$ sodiun chloride/l). At the times indicated the loops were rapidly excised and the remaining carcase assayed for ${ }^{\circ 5} \mathrm{Zn}$ in a whole-body gammacounter. The vertical bars represent the standard error of the means from four to six determinations.

Table 2. Since ligation of the bile duct was without effect most of the $\mathrm{Zn}$ must have been secreted directly from or through the mucosal tissue.

In view of these findings it was decided that in absorption studies involving a time course of $30 \mathrm{~min}$ or less, doses in excess of $1 \mu \mathrm{g} \mathrm{Zn}$ could be used.

\section{${ }^{65} \mathrm{Zn}$ absorption from ligated loops of rat duodenum}

Short time-course of ${ }^{65} \mathrm{Zn}$ absorption. The results of a study of the early time-course of the absorption of ${ }^{85} \mathrm{Zn}$ from a $5 \mu \mathrm{g}$ test dose of $\mathrm{Zn}$ instilled into the lumen of ligated duodenal loops is shown in Fig. 2. This experiment demonstrated that the onset of $\mathrm{Zn}$ absorption was extremely rapid with $>1 \%$ of the test dose being transferred to the carcase I min after dosing.

The kinetics of ${ }^{65} \mathrm{Zn}$ absorption and binding by ligated duodenal loops

$\mathrm{Zn}$ absorption and binding were measured from 5 to $60 \mathrm{~min}$ after duodenal dosing in doses ranging from I to $200 \mu \mathrm{g}$. At all doses, the amount of ${ }^{85} \mathrm{Zn}$ absorbed increased approximately 


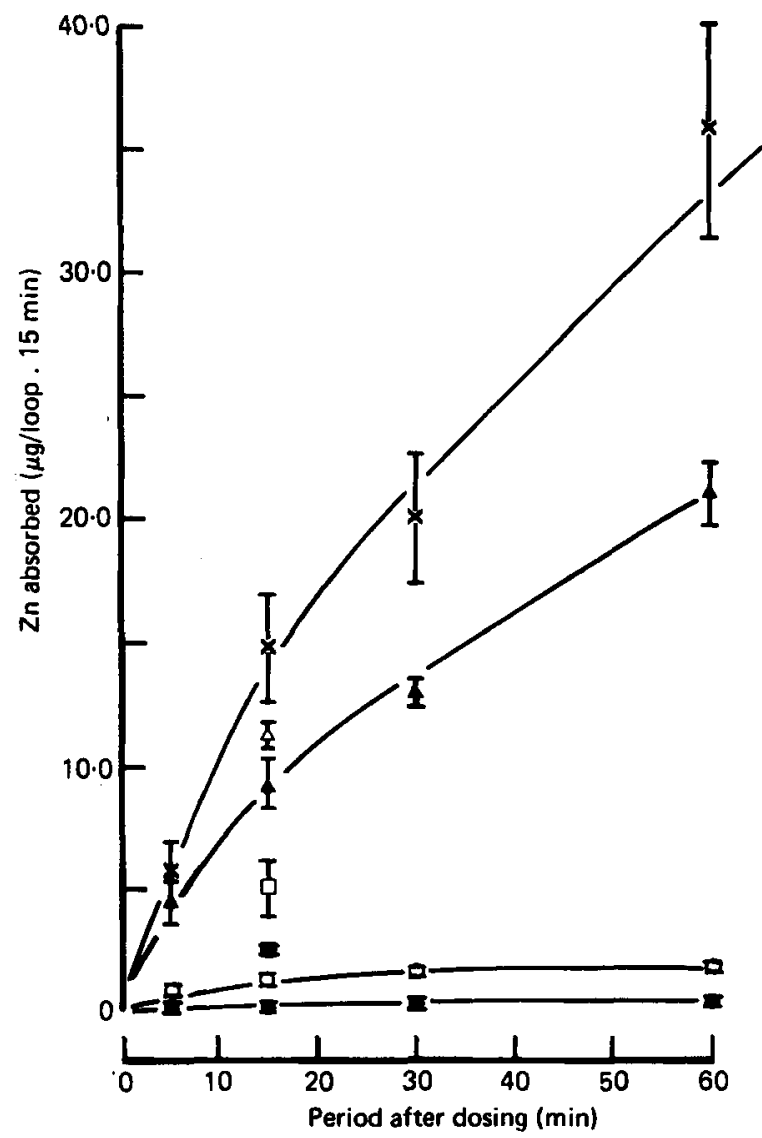

Fig. 3. Time-course of the absorption of different doses of zinc. Ligated loops of rat duodenum were filled with $\mathrm{I} \cdot 0 \mathrm{ml}$ saline $(9 \mathrm{~g}$ sodium chloride/l) containing from $\mathrm{I}-200 \mu \mathrm{g} \mathrm{Zn}$ (labelled with $0 . \mathrm{I}$ $\left.\mu \mathrm{Ci}{ }^{65} \mathrm{Zn}\right)$. At the times shown the loops were excised and $\mathrm{Zn}$ absorption measured as the loss of ${ }^{\circ} \mathrm{Zn}$ contents. (O-O), $1 \mu \mathrm{g} ;(\mathrm{O}-\mathrm{O}), 5.0 \mu \mathrm{g} ;(\square-\square), 10 \mu \mathrm{g} ;(\square-\square), 25 \mu \mathrm{g} ;(\Delta-\Delta), 50 \mu \mathrm{g}$; $(\Delta-\Delta), 100 \mu \mathrm{g} ;(\times-\times), 200 \mu \mathrm{g}$. The vertical bars represent the standard errors of the mean from five to eight determinations.

linearly with time over the first $15 \mathrm{~min}$, after which a fall-off in rate was observed (Fig. 3).

When the amounts of $\mathrm{Zn}$ absorbed in $15 \mathrm{~min}$ were plotted $v$. the dose of $\mathrm{Zn}$, it was apparent that the amount absorbed increased in a curvilinear fashion towards a maximal transport rate (Fig. $4(a)$ ). When these results were plotted in the double-reciprocal manner of Lineweaver-Burke, a linear relationship characteristic of enzymic or 'carrier-mediated' processes was observed (Fig. $4(b)$ ). A Michaelis-Menten constant $\left(K_{m}\right)$ of $139.7 \mu \mathrm{g} \mathrm{Zn/ml}$ and maximal rate $\left(V_{\max }\right)$ of $32 \cdot 3 \mu \mathrm{g} \mathrm{Zn/15} \mathrm{min} \mathrm{were} \mathrm{derived} \mathrm{from} \mathrm{the} \mathrm{intercepts} \mathrm{on} \mathrm{the}$ abcissa and ordinate respectively of the regression line of this double-reciprocal plot.

'Zinc-binding' similarly showed linear increases with time over the first $15 \mathrm{~min}$. A plot of amounts of ${ }^{85} \mathrm{Zn}$ bound in $15 \mathrm{~min} v$. dose showed a biphasic curve (Fig. $5(a)$ ). Doses from $\mathrm{I}$ to $50 \mu \mathrm{g} \mathrm{Zn}$ exhibited saturation kinetics as indicated by a linear relationship when plotted in a double-reciprocal manner. A $K_{m}$ of $48 \cdot 2 \mu \mathrm{g} / \mathrm{ml}$ and $V_{\max }$ of $14.3 \mu \mathrm{g} \mathrm{Zn} / 15 \mathrm{~min}$ were derived from these values (Fig. $5(b)$ ). Above a $50 \mu \mathrm{g}$ dose, the amount of ${ }^{\circ} \mathrm{Zn}$ bound increased in an approximately linear fashion with increasing dose and possibly resulted from non-specific adsorption on to the mucosa. 

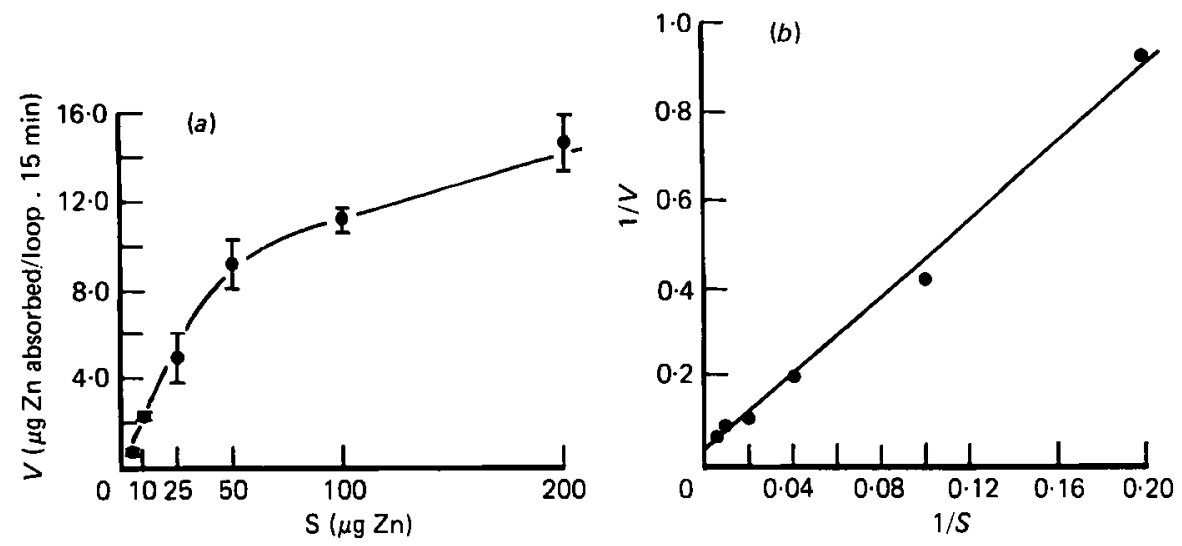

Fig. 4. The kinetics of zinc absorption. (a) The rate of ${ }^{85} \mathrm{Zn}$ absorption ( $\mu \mathrm{g} / \mathrm{loop}$ ) measured $15 \mathrm{~min}$ after dosing ligated duodenal loops in situ $(V) v$. the initial $\mathrm{Zn}$ dose $(\mu \mathrm{g} ; S)$. Each point is the mean from five to eight determinations with their standard errors represented by vertical bars. (b) Doublereciprocal plot of the rates of $\mathrm{Zn}$ absorption $(1 / V) v$. initial $\mathrm{Zn}$ dose $(1 / S)$ after the manner of Lineweaver-Burke.
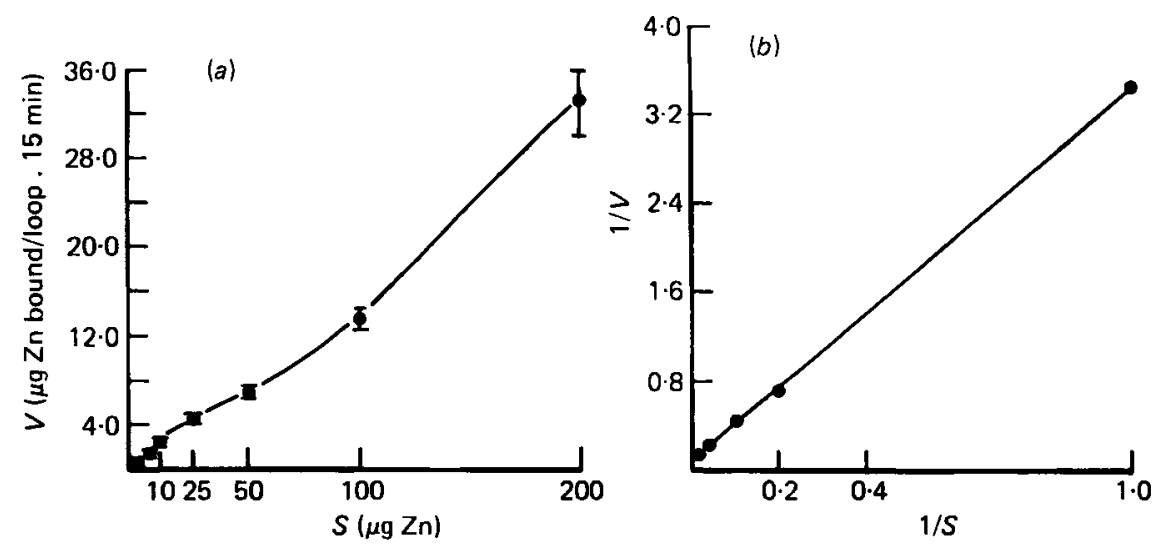

Fig. 5. The kinetics of zinc binding. (a) The rate of ${ }^{65} \mathrm{Zn}$ binding $(\mu \mathrm{g} / \mathrm{loop} ; V)$ measured $15 \mathrm{~min}$ after dosing ligated duodenal loops in situ $v$. the initial dose $(\mu \mathrm{g} ; S)$. Each point is the mean of from five to eight determinations with their standard errors represented by vertical bars. (b) Doublereciprocal plot of the rates of $\mathrm{Zn}$ binding (1/V) against initial doses of $\mathrm{Zn}$ of $\mathrm{I}-50 \mu \mathrm{g} / \mathrm{ml}(1 / S)$ after the manner of Lineweaver-Burke.

\section{The fate of $\mathrm{Zn}$ bound to loop tissue}

In the experiments described previously it was noted that at the lowest dose (I $\mu \mathrm{g} \mathrm{Zn})$ the mean $( \pm \mathrm{SE})$ amount of ${ }^{85} \mathrm{Zn}$ bound $(\mu \mathrm{g})$ at 60 min after dosing $(0.20 \pm 0.01 \mathrm{n} 6)$ was $30 \%$ less $(P<0.01)$ than that bound at $30 \mathrm{~min}(0.29 \pm 0.02 \mathrm{n6})$ indicating that either some of the bound $\mathrm{Zn}$ had been secreted back into the luminal fluid or that at least a proportion of the bound $\mathrm{Zn}$ was in a pool which was subsequently transferred to the carcase. In order to determine the fate of the ${ }^{65} \mathrm{Zn}$ bound to the loop tissue, an experiment was performed in which loops were filled with $5 \mu \mathrm{g}$ doses of ${ }^{65} \mathrm{Zn}$, flushed out 15 min later and immediately refilled with I $\mathrm{ml} \mathrm{Zn}$-free saline. At varying times from $15 \mathrm{~min}$ to $6 \mathrm{~h}$ after this procedure the loops were excised and the ${ }^{65} \mathrm{Zn}$ activity in the luminal contents and loops tissue assayed.

Virtually none $\left(<\mathrm{I} \%\right.$ ) of the remaining ${ }^{65} \mathrm{Zn}$ was recovered in the mucosal fluid indicating 


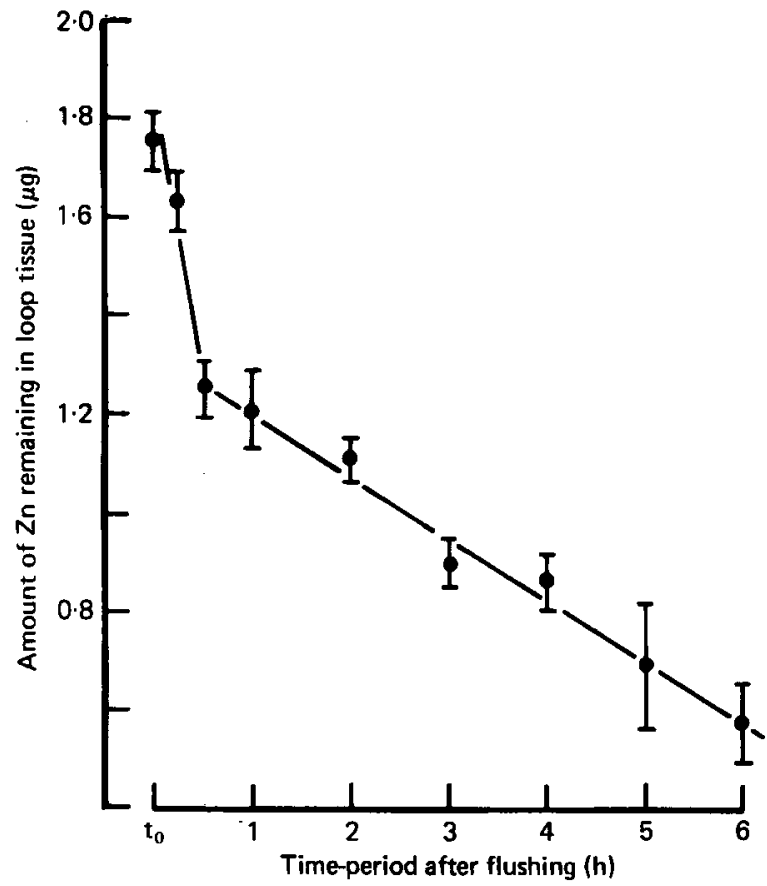

Fig. 6. The loss of mucosally bound zinc to the body. A $5 \mu \mathrm{g}$ test dose of $\mathrm{Zn}$ labelled with $0 \cdot 1 \mu \mathrm{Ci}$ ${ }^{85} \mathrm{Zn}$ in $1 \mathrm{ml}$ saline $(9 \mathrm{~g}$ sodium chloride/l) was injected into ligated loops of duodenum cannulated at each end with closed lengths of Portex tubing. After $15 \mathrm{~min}$ the loops were flushed out in situ and refilled with saline. Loops were excised either immediately $\left(t_{0}\right)$ or from 15 min to $6 \mathrm{~h}$ later and the ${ }^{65} \mathrm{Zn}$ remaining in the loop content assayed. Each point is the mean of four to twelve determinations with their standard errors represented by vertical bars.

that bound ${ }^{65} \mathrm{Zn}$ was not re-excreted into the lumen of the gut. However there was a progressive loss of ${ }^{65} \mathrm{Zn}$ activity from the loop plus contents over the time-period studied. Over the first $30 \mathrm{~min}$ the rate of ${ }^{65} \mathrm{Zn}$ loss to the carcase was rapid (Fig. 6) while from 30 min to $6 \mathrm{~h}{ }^{65} \mathrm{Zn}$ was slowly lost to the carcase at a rate which was approximately linear with time. These results may be indicative of two phases of ${ }^{85} \mathrm{Zn}$ absorption, a rapid phase occurring within minutes of contact of a dose of ${ }^{85} \mathrm{Zn}$ with the mucosal tissue and a slower phase of absorption involving transfer to the carcase of $\mathrm{Zn}$ which had previously bound to the mucosal tissue. The ${ }^{65} \mathrm{Zn}$ that was rapidly lost over the first $30 \mathrm{~min}$ may therefore have been in a pool associated with the rapid phase of absorption whilst that transferred slowly to the carcase at later times may have been associated with a second, slower phase of $\mathrm{Zn}$ absorption.

This second phase of $\mathrm{Zn}$ absorption was investigated more fully in experiments in which different doses of ${ }^{65} \mathrm{Zn}$ (from I to $50 \mu \mathrm{g} \mathrm{Zn}$ ) were instilled for $15 \mathrm{~min}$ in duodenal loops before flushing out of the residual luminal ${ }^{65} \mathrm{Zn}$ and refilling with saline as described previously. The amount of ${ }^{65} \mathrm{Zn}$ remaining in the loops and contents were determined at I and $3 \mathrm{~h}$ after filling with $\mathrm{Zn}$-free saline (Table 3). At all doses ${ }^{65} \mathrm{Zn}$ was lost more rapidly from the loops over the first hour than from $\mathrm{I}$ to $3 \mathrm{~h}$ of the experimental period. In order to investigate the kinetics of this slow phase of $\mathrm{Zn}$ transfer to the carcase the mean rates of loss of ${ }^{65} \mathrm{Zn}$ from the loops from $\mathrm{I}$ to $3 \mathrm{~h}$ were plotted $v$. the mean ${ }^{65} \mathrm{Zn}$ contents at $\mathrm{I} \mathrm{h}$ after the flushing procedure for each of the initial ${ }^{65} \mathrm{Zn}$ doses. The results shown in Fig. 7 indicate that this process is saturable, consistent with an enzymic or 'carrier-mediated' process. 
Table 3. The recovery of ${ }^{65} \mathrm{Zn}$ in duodenal tissue immediately after flushing out the test dose o ${ }^{65} \mathrm{Zn}\left(t_{0}\right)$ and $\mathrm{I}$ and $3 \mathrm{~h}$ later

(Mean values with their standard errors; nos. of animals/treatment given in parentheses. The doses of $\mathrm{Zn}$ (labelled with $1 \mu \mathrm{Ci}{ }^{85} \mathrm{Zn}$ ) were instilled into cannulated ligated duodenal loops in situ and 15 min later $\left(t_{0}\right)$, the residual ${ }^{25} \mathrm{Zn}$ was flushed out with $10 \mathrm{ml}$ warm saline $(9 \mathrm{~g}$ sodium chloride/l) by means of two cannulas, one at each end of the ligated segment)

\begin{tabular}{|c|c|c|c|c|c|c|}
\hline \multirow{3}{*}{$\begin{array}{l}\text { Initial dose } \\
{ }^{85} \mathrm{Zn}(\mu \mathrm{g})\end{array}$} & \multicolumn{6}{|c|}{ Recovery of ${ }^{\circ B} \mathrm{Zn}$ in loop tissue $(\mu \mathrm{g})$} \\
\hline & \multicolumn{2}{|c|}{$t_{0}$} & \multicolumn{2}{|c|}{ I h } & \multicolumn{2}{|c|}{$3 \mathrm{~h}$} \\
\hline & Mean & SE & Mean & SE & Mean & SE \\
\hline I & $0.4 \mathrm{I}$ & $0.03(4)$ & 0.33 & $0.02(4)$ & 0.24 & $0.02 \quad(4)$ \\
\hline 5 & I·75 & $0.06(6)$ & I.2I & $0.08(6)$ & 0.90 & $0.05(12)$ \\
\hline 25 & $6 \cdot 60$ & $0.44(4)$ & 4.49 & $0.45(4)$ & $2 \cdot 3 \mathbf{I}$ & $0.10 \quad(4)$ \\
\hline 50 & $11 \cdot 56$ & $0.84(4)$ & $9 \cdot 60$ & $0.85(5)$ & $7 \cdot 29$ & $0.55 \quad(4)$ \\
\hline
\end{tabular}

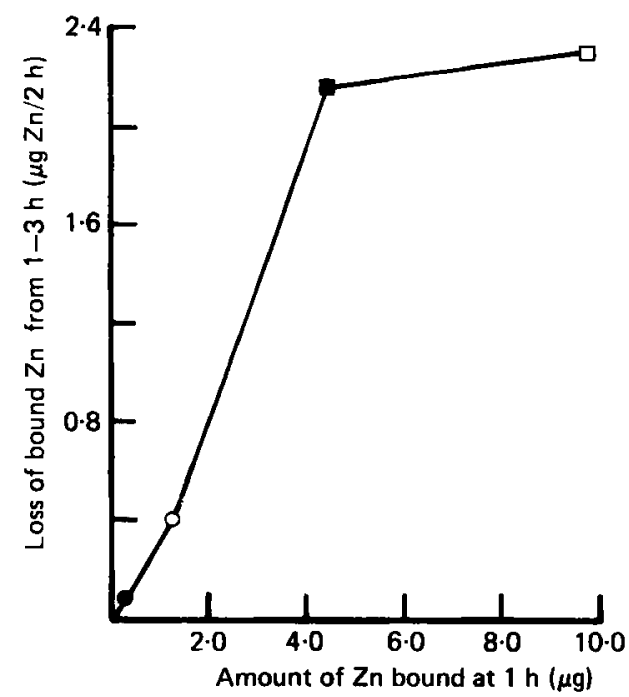

Fig. 7. The kinetics of the slow loss of mucosally bound ${ }^{8 x} \mathrm{Zn}$ to the body. The rate of loss of $\mathrm{Zn}$ from $\mathrm{I}-3 \mathrm{~h}$ after binding refers to the difference in the mean recoveries of ${ }^{65} \mathrm{Zn}$ in loops plus contents $\mathrm{I} \mathrm{h}$ and $3 \mathrm{~h}$ after $\mathrm{a} 15 \mathrm{~min}$ exposure of the mucosal tissue to 0,$1 ; 0,5 ; 0,25$ or $\square$, $50 \mu \mathrm{g}$ doses of $\mathrm{Zn}$ labelled with $0.1 \mu \mathrm{Ci}^{55} \mathrm{Zn}$ in $1.0 \mathrm{ml}$ saline $(9 \mathrm{~g}$ sodium chloride/l). These values are plotted $v$. the means of the recoveries of ${ }^{65} \mathrm{Zn}$ in loops plus contents for each of the doses at $\mathrm{I} \mathrm{h}$ after the initial binding. For each time and at each dose tested at least six separate determinations were made.

The effect of $\mathrm{Zn}$ on the mucosal uptake of glucose, arginine and fluid

While the results of both kinetic studies described previously are consistent with enzyme or 'carrier-mediated' processes it was possible that the decreased fractional rates of Zn transfer to the carcase noted at high $\mathrm{Zn}$ doses may have resulted from toxic action of the high concentration of $\mathrm{Zn}^{2}+$ on the mucosal tissue. However, histological examination of the mucosa of duodenal loops filled for $\mathrm{I} \mathrm{h}$ with $1 \mathrm{ml}$ saline containing $200 \mu \mathrm{g} \mathrm{Zn}$ revealed no discernible difference from those similarly treated but filled with $1 \mathrm{ml}$ saline alone. In order to assess whether the high $\mathrm{Zn}$ concentrations may have impaired the absorptive function of the mucosal tissue, separate studies were made of the effects of $200 \mu \mathrm{g} \mathrm{Zn} / \mathrm{ml}$ on the mucosal uptake of glucose, arginine and fluid by isolated duodenal loops. The results are shown 
Table 4. The effect of zinc (200 $\mu \mathrm{g} / \mathrm{ml})$ on the mucosal uptake (Jloop per $15 \mathrm{~min})$ of glucose $(\mu \mathrm{mol})$, arginine $(\mu \mathrm{mol})$ and fuid $(\mathrm{ml})$ by ligated duodenal loops in situ

(Mean values with their standard errors; nos. of rats/treatment given in parentheses. In all experiments the loops contained $1 \mathrm{ml}$ saline $(9 \mathrm{~g}$ sodium chloride/l) to which was added either $10 \mu \mathrm{mol}$ D-glucose or $6.9 \mu \mathrm{mol} \mathrm{L}$-arginine. Statistical analysis was by Student's $t$ test)

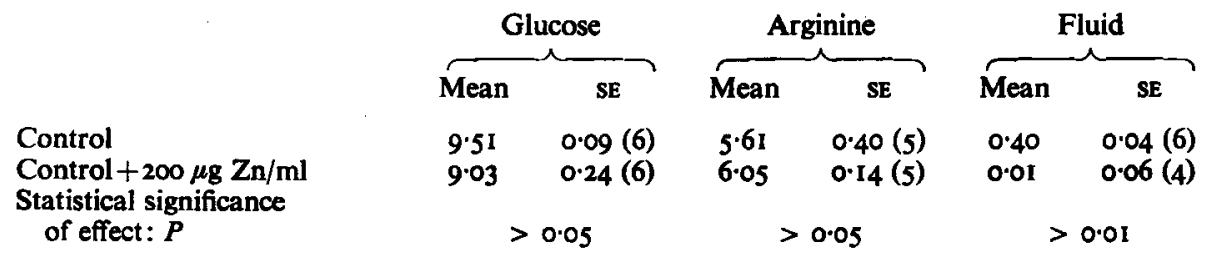

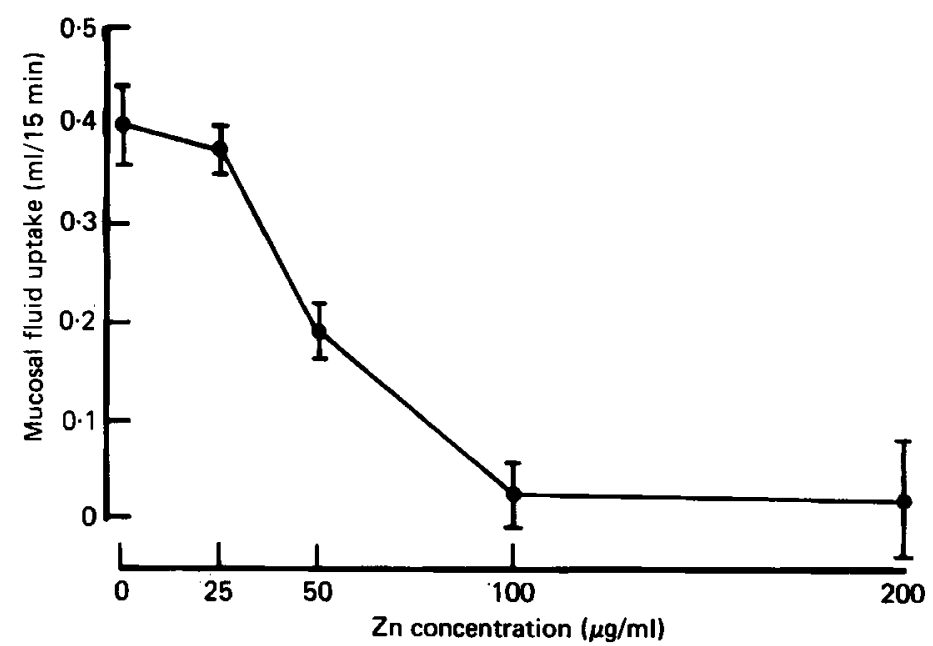

Fig. 8. The effect of zinc on mucosal fluid uptake by ligated duodenal loops in situ. Loops were injected with I ml saline (9 g sodium chloride/l) containing from o to $200 \mu \mathrm{g} \mathrm{Zn}$. After $15 \mathrm{~min}$ loops were removed and the loss of fluid, determined by weight, used as a measure of mucosal fluid uptake. Each point is the mean of six determinations with their standard errors represented by vertical bars.

in Table 4. $\mathrm{Zn}(200 \mu \mathrm{g} / \mathrm{ml})$ was without significant effect on the uptake of glucose or arginine although at this concentration fluid uptake was virtually abolished. A study of the effect of different concentrations of $\mathrm{Zn}$ on fluid transfer revealed that $50 \mu \mathrm{g} \mathrm{Zn} / \mathrm{ml}$ inhibited by $>50 \%$ and $100 \mu \mathrm{g} / \mathrm{ml}$ by $>90 \%$ compared with the transfer rate by loops containing saline alone (Fig. 8).

\section{DISCUSSION}

The results of the study of absorption of ${ }^{65} \mathrm{Zn}$ from different regions of the intestine by a modification of the technique of Heth \& Hoekstra (1965) demonstrate clearly the importance of the duodenum as the major site of $\mathrm{Zn}$ absorption. These results confirm the conclusions of Methfessel \& Spencer (1973a) and Van Campen \& Mitchell (I965) who compared the rates of uptake of ${ }^{65} \mathrm{Zn}$ from ligated intestinal segments. The limitations of this latter technique have been emphasized by Becker \& Hoekstra (197I) who point out that the total amount of ${ }^{65} \mathrm{Zn}$ absorbed by different regions of the intestine will depend both upon the 
rate of absorption and the length of time a given portion of the ${ }^{65} \mathrm{Zn}$ remains in contact with each particular intestinal region.

In view of this, it seems likely that the significant contribution to over-all $\mathrm{Zn}$ absorption made by the terminal ileum in this present study probably reflects the slower rate of passage of isotope through this region compared with the more proximal regions. Preliminary studies involving injections of ${ }^{139} \mathrm{CeCl}_{3}$ as a non-absorbed marker under identical conditions as were used in the ${ }^{65} \mathrm{Zn}$ absorption study, support this conclusion. Thus in duodenally dosed animals the ${ }^{199} \mathrm{Ce}$ had cleared the first $200 \mathrm{~mm}$ of the small intestine by $\mathrm{I} h$ whereas it took $4 \mathrm{~h}$ to clear the mid-jejunal and upper ileal region in jejunally dosed animals, and over $7.5 \mathrm{~h}$ to clear the terminal ileal region in animals dosed $200 \mathrm{~mm}$ proximally from the ileo-caecal junction (N. T. Davies, unpublished observations). In agreement with the conclusion of both Methfessel \& Spencer (1973a) and Van Campen \& Mitchell (I965), the caecum and colon contributed little to the over-all absorption of $\mathrm{Zn}$.

The mechanisms involved in the intestinal absorption of $\mathrm{Zn}$ have not yet been characterized although the possibility of absorption by a 'carrier-mediated' process has been inferred both from competition studies and Zn balance trials. Van Campen (1966) and Van Campen \& Scaife (I967) demonstrated that high concentrations of $\mathrm{Zn}$ inhibit $\mathrm{Cu}$ absorption from ligated loops of rat duodenum and conversely that high concentrations of $\mathrm{Cu}$ inhibit $\mathrm{Zn}$ absorption, indicating these elements shared a common absorptive pathway and hence could not be absorbed by simple diffusion.

Conventional $\mathrm{Zn}$ balance trials in rats (Likuski \& Forbes, I965) and studies of ${ }^{65} \mathrm{Zn}$ balances in rats (Ballou \& Thompson, 196I ; Furchner \& Richmond, 1962 ; Heth \& Hoekstra, 1965) and mice (Rubini et al. I96I) have sometimes yielded conflicting results. Some of these differences may have been due to limitations of the techniques employed as discussed by Becker \& Hoekstra (1971).

The experiments on the rapid phase of ${ }^{65} \mathrm{Zn}$ absorption reported here demonstrate clearly that $\mathrm{Zn}$ is absorbed from the rat duodenum by a saturable mechanism consistent with an enzyme or 'carrier-mediated' process (Fig. 4(a)). An alternative explanation of the decreased fractional absorption of ${ }^{85} \mathrm{Zn}$ at high $\mathrm{Zn}$ doses namely that high intraluminal concentrations of zinc ions exerted a general toxic action on the absorbing cells seems unlikely in view of the lack of effect of the highest $\mathrm{Zn}$ dose $(200 \mu \mathrm{g} / \mathrm{ml})$ on either glucose or arginine uptake by isolated duodenal loops. Both of these nutrients are taken up by the intestinal mucosa by active transport mechanisms and hence a non-specific poisoning of the mucosa would have produced an inhibition of these processes. In addition, the failure to demonstrate histological damage to the intestinal mucosa following exposure to a $200 \mu \mathrm{g} / \mathrm{ml}$ dose of $\mathrm{Zn}$ again makes this explanation unlikely. In view of these observations it seems likely that the inhibitory effects of $\mathrm{Zn}$ on fluid absorption when present in the loops at concentrations in excess of $50 \mu \mathrm{g} / \mathrm{ml}$ (Fig. 8) were due to specific actions on the fluid transport process rather than a consequence of a general disturbance of metabolic function. Forth \& Rummel (197I) have similarly demonstrated that a high concentration of $\mathrm{Zn}(325 \mu \mathrm{g} / \mathrm{ml})$ inhibited fluid absorption by ligated loops of rat jejunum in situ, whereas it barely affected glucose absorption.

Although the kinetics evidence presented in Fig. 4 $(a \& b)$ points to $\mathrm{Zn}$ being absorbed by a 'carrier-mediated' process it seems unlikely that saturation of this process would occur under normal nutritional circumstances. In a few determinations of $\mathrm{Zn}$ contents of gastric and duodenal digesta from rats maintained on either a conventional pelleted stock diet containing $80 \mu \mathrm{g} \mathrm{Zn/g}$ or the semi-synthetic diet of Williams \& Mills (1970) supplemented with $\mathrm{ZnSO}_{4}$ to give a $\mathrm{Zn}$ content of $40 \mu \mathrm{g} / \mathrm{g}$, the concentrations of soluble $\mathrm{Zn}$ ranged from $5^{-22} \mu \mathrm{g} / \mathrm{ml}$. These concentrations should be compared with the concentration required to give half maximal rate of $\mathrm{Zn}$ absorption by the duodenum $\left(K_{m}\right)$ of $139.7 \mu \mathrm{g} / \mathrm{ml}$ (Fig. 4) as found in the present investigation. Since the absorption of any nutrient by a particular 
region of the intestine depends not only on the rate of the absorptive process but also the length of time the nutrient is in contact with the absorbing surface it would seem likely that the rate of passage of digesta through the duodenal region into more distal regions, where $\mathrm{Zn}$ absorption is less efficient, may be of importance in determining the extent of overall absorption of available $\mathbf{Z n}$.

The rapid time-course of $\mathrm{Zn}$ transfer from the intestinal lumen to the body shown in Figs. 2 and 3 is similar to the recent findings of Smith et al. (1978). These workers detected ${ }^{65} \mathrm{Zn}$ in portal blood within $5 \mathrm{~min}$ of the start of luminal perfusion of rat intestine in vivo with a solution containing ${ }^{65} \mathrm{Zn}$. A similar time-course of appearance of ${ }^{65} \mathrm{Zn}$ in the vascular perfusate of rat intestine was observed in an isolated, luminally and vascularly perfusate preparation in vitro.

The studies of the kinetics of ${ }^{65} \mathrm{Zn}$ binding to the loop tissue suggested that at the lower doses $(\mathrm{I}-50 \mu \mathrm{g} \mathrm{Zn}){ }^{65} \mathrm{Zn}$ bound to a specific saturable site whereas at higher doses (50-200 $\left.\mu \mathrm{g}\right)$ binding appeared to be non-specific (Fig. 5a). Two findings suggest that at the lower doses a proportion of this bound ${ }^{65} \mathrm{Zn}$ was in a pool associated with the rapid $\mathrm{Zn}$ transfer process. First the amount of ${ }^{85} \mathrm{Zn}$ bound to the mucosa $60 \mathrm{~min}$ after dosing ligated loops with $\mathrm{I} \cdot 0$ $\mu \mathrm{g} \mathrm{Zn}$ was significantly lower than that bound at $30 \mathrm{~min}$. Secondly, in the experiment in which the fate of mucosally bound ${ }^{65} \mathrm{Zn}$ was examined after dosing with a $5 \mu \mathrm{g}$ dose of ${ }^{65} \mathrm{Zn}$, the loss of bound ${ }^{65} \mathrm{Zn}$ over the first $30 \mathrm{~min}$ was rapid and corresponded to almost $30 \%$ of the amount initially bound. This loss was due entirely to movement into the body and not re-entry into the luminal fluid.

Recently Evans et al. (1975) have proposed a mechanism of $\mathrm{Zn}$ absorption involving secretion of a low-molecular-weight $\mathrm{Zn}$-binding ligand from the pancreas, which binds luminal $\mathrm{Zn}$ and this $\mathrm{Zn}$-ligand complex is then transported through the mucosal membrane and into the cell (Evans \& Hahn, 1974; Evans \& Johnson, 1978). Evans (1976) has suggested that the removal of $\mathrm{Zn}$ from the baso-lateral membrane is the rate-limiting step to $\mathrm{Zn}$ absorption, and this may be determined by the amount of either $\mathrm{Zn}$-free albumen or transferrin in the blood circulating through the intestinal vasculature.

The results of this present investigation are not entirely consistent with these proposals. The kinetics of $\mathrm{Zn}$ binding and absorption within a dose range of $\mathrm{I}-50 \mu \mathrm{g} \mathrm{Zn}$ showed that at all doses the rate of absorption exceeded the rate of binding and that whereas the proportion of $\mathrm{Zn}$ bound decreased as the dose was increased from 25 to $50 \mu \mathrm{g} \mathrm{Zn}$, absorption showed no such decrease (Figs $4(a)$ and $5(a)$ ). These results indicate that the loss of $\mathrm{Zn}$ from the mucosal cells to the blood was not rate-limiting to the absorption mechanism when $\mathrm{Zn}$ was present in the intestinal loop at concentrations encountered under normal nutritional circumstances.

Furthermore, in an experiment designed to investigate a possible role of pancreatic secretions on $\mathrm{Zn}$ absorption, $100 \mathrm{~mm}$ long ligated loops were prepared in which the proximal ligature was tied either just proximal to or distal to the common bile and pancreatic duct. In the former loops which were exposed to biliary and pancreatic secretions, mean $( \pm S E)$ $\mathrm{Zn}$ absorption from a $5 \mu \mathrm{g}$ test dose of $\mathrm{Zn}$ was $(\mu \mathrm{g} \mathrm{Zn} /$ loop per $15 \mathrm{~min}) 0.55 \pm 0.06(n)$ compared with $0.5 \mathrm{I} \pm 0.04(n 6)$ in the latter loops from which these secretions were excluded $(P>0.05)$. Clearly further studies on the kinetics of $\mathrm{Zn}$ binding to pancreatic secretions and $\mathrm{Zn}$ uptake by mucosal cells in conjunction with investigations on the nature of $\mathrm{Zn}$-binding ligands in portal blood and measurements of blood flow-rates through the mucosa are needed to test the validity of the proposals of Evans and his co-workers (Evans \& Hahn, 1974; Evans et al. 1975; Evans, 1976; Evans \& Johnson, 1978).

The studies reported here also show that in addition to the rapid phase of $\mathrm{Zn}$ absorption, a slower phase of absorption occurred involving the transfer to the body of bound ${ }^{65} \mathrm{Zn}$ over a period of up to $6 \mathrm{~h}$ after the initial binding. Since the rate of this process exhibited 
saturation when plotted $v$. the amount of ${ }^{65} \mathrm{Zn}$ bound, it would suggest at high mucosal $\mathrm{Zn}$ contents the release of $\mathrm{Zn}$ to the blood was rate-limiting and involved an enzyme or 'carriermediated' process.

It is not possible from these results to quantify the relative contribution each of these apparently-distinct $\mathrm{Zn}$ absorption processes would make to the over-all absorption of dietary $\mathrm{Zn}$, although a comparison of the kinetic information indicates that the slow phase would play a minor role. The maximal rate of ${ }^{65} \mathrm{Zn}$ transfer by this process as measured in this study was $2 \cdot 5-3.0 \mu \mathrm{g} \mathrm{Zn} / 2 \mathrm{~h}$ (Fig. 6), and thus at most could be responsible for the absorption of $30-36 \mu \mathrm{g} \mathrm{Zn} / \mathrm{d}$. This can be compared with a retention of dietary $\mathrm{Zn}$ of I 20 $130 \mu \mathrm{g} / \mathrm{d}$ by rats of identical strain, age and weight, measured in a previous investigation (Davies \& Nightingale, 1975). However, the duodenal loops used in this current investigation represented approximately one-fifth of the total length of the small intestine and if this mechanism were to operate to a similar extent in other regions of the gut, absorption by this slow phase could make an important contribution to over-all $\mathrm{Zn}$ absorption. Furthermore, if as has already been suggested the rapid passage of digesta through the duodenal region may limit the extent of $\mathrm{Zn}$ absorption by the rapid absorptive process, the ability of the mucosa to bind $\mathrm{Zn}$ and then transfer it slowly to the body may be of quantitative significance.

Recent findings by Cousins and his co-workers (Richards \& Cousins, 1976, 1977; Smith et al. 1978) have shown that the major $\mathrm{Zn}$-binding fraction in the cytosol of mucosal cells is metallothionein. These workers have suggested that this ligand may play a key role in the regulation of the extent of $\mathrm{Zn}$ absorption. They suggest that $\mathrm{Zn}$ taken up into the intestinal cells may either be transported across the serosal membranes into the hepatic portal blood or become bound within the cells to metallothionein which prevents its transfer to the plasma. Thus the amount of metal-free thionein in the $\mathrm{Zn}$-absorbing cells of the mucosa may be the major determinant of the extent of $\mathrm{Zn}$ absorption (reviewed by Cousins, 1978).

The results of this present study neither conflict with nor confirm these proposals. In the studies of Cousins and co-workers in which an inverse relationship between ${ }^{65} \mathrm{Zn}$ absorption and ${ }^{65} \mathrm{Zn}$ binding to metallothionein has been demonstrated both in vivo (Richards \& Cousins, 1976; Smith et al. 1978) and in vitro (Smith et al. 1978) either carrier-free ${ }^{65} \mathrm{Zn}$ was given by stomach tube, or the intestinal preparations were perfused with very low concentrations of $\mathrm{Zn}(0.52 \mu \mathrm{g} / \mathrm{ml})$. Whether similar relationships occur when doses of $\mathrm{Zn}$ similar to those normally encountered in the intestinal contents, such as have been employed in the present investigation, have yet to be established.

In conclusion this study has described the rates of doudenal $\mathrm{Zn}$ binding and absorption in relation to time-period after dosing, size of dose, and possible toxic effects of high intraluminal $\mathrm{Zn}^{2}+$ concentrations on intestinal transfer processes and it is hoped that using these results, future studies on the kinetics of $\mathrm{Zn}$ binding to specific mucosal ligands will allow fuller characterization of the $\mathrm{Zn}$ absorptive mechanisms to be made.

The author gratefully acknowledges the expert technical assistance of $\mathrm{Mr} \mathrm{A}$. Flett.

\section{REFERENCES}

Ballou, J. E. \& Thompson, R. C. (1961). Hlth Phys. 6, 6.

Becker, W. M. \& Hoekstra, W. G. (I97I). In Intestinal Absorption of Metal Ions, Trace Elements and Radionuclides, p. 229. [S. C. Skoryna and D. Waldron-Edward, editors]. Oxford: Pergamon.

Cotzias, G. C., Borg, D. C. \& Selleck, B. (1962). Am. J. Physiol. 202, 359.

Cousins, R. J. (1978). Proc. 3 rd int. Symp. Trace Element Metabolism in Man and Animals, p. 57.

Davies, N. T. (1973). J. Physiol., Lond. 229, 46.

Davies, N. T. \& Nightingale, R. (I975). Br. J. Nutr. 34, 243.

Evans, G. W. (1976). Proc. Soc. exp. Biol. Med. 15x, 775.

Evans, G. W., Grace, C. I. \& Votava, H. J. (1975). Am. J. Physiol. 228, 50 I. 
Evans, G. W. \& Hahn, C. J. (1974). In Advances in Experimental Medicine and Biology, p. 285. [M. Friedman, editor] New York: Plenum Press.

Evans, G. W. \& Johnson, P. E. (1978). Proc. 3rd int. Symp. Trace Element Metabolism in Man and Animals, p. 98.

Evans, G. W., Majors, P. F. \& Cornatzer, W. R. (1970). Res. Commun. 40, 1142.

Feaster, J. P., Hansard, S. L., McCall, J. T. \& Davies, G. K. (1955). Am. J. Physiol. 181, 287.

Forbes, R. M. (1961). J. Nutr. 74, 194.

Forbes, R. M. \& Yohe, M. (1960). J. Nutr. 70, 53.

Forth, W. \& Rummel, W. (197I). In Intestinal absorption of Metal lons, Trace Elements and Radionuclides, p. 173. [S. C. Skoryna and D. Waldron-Edward, editors]. Oxford: Pergamon.

Furchner, J. E. \& Richmond, C. R. (1962). Hith Phys. 8, 35.

Heth, D. A. \& Hoekstra, W. G. (1965). J. Nutr. 35, 367.

Kowalski, S., Blair-Stanek, C. S. \& Schacter, D. (1974). Am. J. Physiol. 226, 401.

Likuski, H. J. A. \& Forbes, R. M. (1965). J. Nutr. 85, 230.

Macpherson, H. T. (1942). Biochem. J. 36, 59 .

Methfessel, A. H. \& Spencer, H. (1973a). J. appl. Physiol. 34, 58.

Methfessel, A. H. \& Spencer, H. (1973 b). J. appl. Physiol. 34, 63.

Nelson, N. (1944). J. biol. Chem. 153, 375.

Richards, M. P. \& Cousins, R. J. (1976). J. Nutr. 106, 159.

Richards, M. P. \& Cousins, R. J. (1977). Biochem. Biophys. Res. Comm. 75, 286.

Rubini, M. E., Montalvo, G., Lockhart, C. P. \& Johnson, C. R. (1961). Am. J. Physiol. 200, 1345.

Smith, K. T., Cousins, R. J., Silbon, B. L. \& Failla, M. L. (1978). J. Nutr. 108, I 849.

Somogyi, M. (1945). J. biol. Chem. 160, 61.

Spencer, M., Vankinscott, V., Lewis, I. \& Samachson, J. (1965). J. Nutr. 86, I69.

Starcher, B. C. (1969). J. Nutr. 97, 321.

Suso, F. A. \& Edwards, H. M. (1971 a). Proc. Soc. exp. Biol. Med. 137, 306.

Suso, F. A. \& Edwards, H. M. (1971 b). Proc. Soc. exp. Biol. Med. 138, 157.

Underwood, E. J. (1971). Trace Elements in Human and Animal Nutrition, 3rd ed., p. 217. London: Academic Press.

Van Campen, D. R. (1966). J. Nutr. 88, 125.

Van Campen, D. R. (1969). J. Nutr. 97, 104.

Van Campen, D. R. \& Kowalski, T. J. (1971). Proc. Soc. exp. Biol. Med. 136, 294.

Van Campen, D. R. \& Mitchell, E. A. (1965). J. Nutr. 86, 20.

Van Campen, D. R. \& Scaife, P. U. (1967). J. Nutr. 91, 473.

Whiting, F. \& Bezeau, L. M. (1958). Can. J. Anim. Sci. 38, 109.

Williams, R. B. \& Mills, C. F. (1970). Br. J. Nutr. 24, 989. 